DOI: $10.2507 / 28$ th.daaam.proceedings.131

\title{
PARAMETRic Versus NonParametric Statistical Process Control
}

\author{
Tereza Smajdorova \& Darja Noskievicova
}
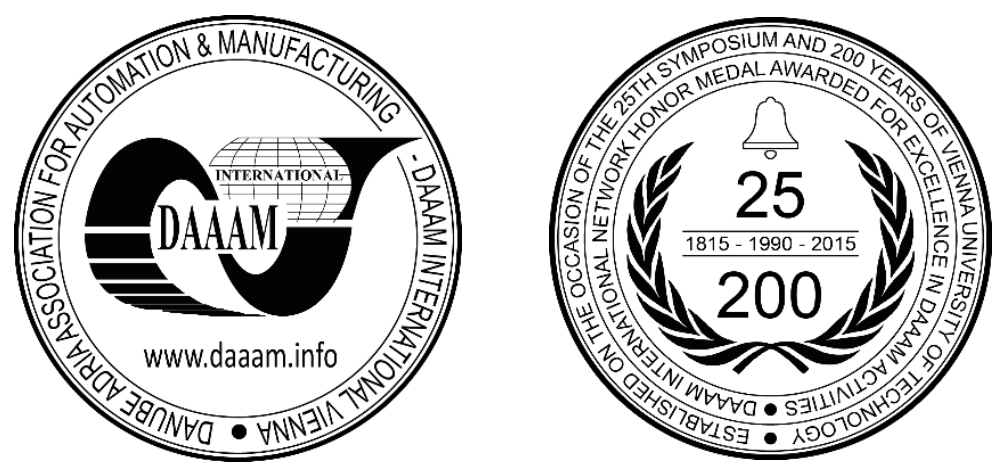

This Publication has to be referred as: Smajdorova, T[ereza] \& Noskievicova, D[arja] (2017). Parametric Versus Nonparametric Statistical Process Control, Proceedings of the 28th DAAAM International Symposium, pp.0944-0949, B. Katalinic (Ed.), Published by DAAAM International, ISBN 978-3-902734-11-2, ISSN 1726-9679, Vienna, Austria DOI: $10.2507 / 28$ th.daaam.proceedings.131

\begin{abstract}
This paper represents the limitations of commonly used parametric methods of statistical process control, especially problems associated with the use of classical Shewhart control charts, and shows the benefits of non-parametric and robust control charts. The aim of this article is to define the various deviations from normality that cause problems in the use of classical parametric methods of statistical process control. Another goal is to define the differences between nonparametric and robust methods and to present these methods as one of the possibilities of solving the problems of normality violations. Finally, there is introduced the development and the future direction and robust nonparametric statistical process control.
\end{abstract}

Keywords: Statistical process control; parametric methods; nonparametric methods; basic data assumptions

\section{Introduction}

One of the main aims of statistical process control is to distinguish between two sources of variability in a given process. These are sources of variability that cannot be economically identified and corrected (common causes) and those that can be identified and subsequently removed (assignable causes). [3,9,21]

- Common causes: The causes that are inherently connected with the process, affect it every day. [4]

- Assignable causes: The causes that do not affect the process continuously, but they arise under various circumstances. [4]

If the process is affected only by the random causes of variability, it is said to be in a state of statistical stability (incontrol). [3,9]. The main tool of statistical process control is the control chart. In case, the process is affected by a assignable cause of variability, the control chart should signal as soon as possible that the process is out of control. Obviously, the faster the effect of the assignable cause of variability is identified, the more effective the control chart is. $[3,9]$ One of the most prominent pioneers in quality management was Walter A. Shewhart, since 1918 the Bell Telephone Laboratory employee. 
In May 1924, he designed the first control chart to assess whether the variability of the monitored process parameter was due to random fluctuations or special causes (machine alignment, change of raw materials, etc.) and laid the foundations for modern industry. [8]

To use these classical Shewhart control charts, the data must meet certain basic assumptions (normality, independence, constant mean and variance). In practice, however, these assumptions often cannot be met. Even so, companies use Shewhart control charts, but it does not have to deliver relevant results. Therefore, their attention should be redirected to non-parametric control charts that are a suitable alternative to the classical Shewhart control charts.

However, nonparametric or robust control charts are not available in current publications or in teaching, whether in schools or courses. There is not enough software support for these alternative methods as well. The aim of this paper is to clarify the problems that may arise when using Shewhart classical control diagrams and to present the advantages of nonparametric methods.

\section{Classical Shewhart control charts}

The classical Shewhart control charts count among the parametric methods of statistical process control. For the use of classical Shewhart control charts, some basic data assumptions must be met. These assumptions include: [5]

1. A general assumption

- compliant capability of the measurement system

2. The basic statistical assumptions

- normal distribution of the quality characteristics,

- constant mean and variance,

- mutual independence of quality characteristics values.

3. The other assumptions

- a sufficient amount of data,

- $\quad$ sensitivity to greater changes in a process,

- monitoring one quality characteristics per unit of a product.

These basic assumptions need to be verified and a number of tests and graphical tools can be used:

- Verification of normality:

- Shapiro - Wilk test [5]

- Shapiro-Francia test [1]

- Royston modification [7]

- Anderson - Darling test [6;10]

- Verification of independence:

- Autocorrelation test [7]

- $\quad$ Test of iterations up and down [5]

- $\quad$ Runs Above and Below the Median [7]

- Verification of Homogeneity of means and variances:

- $\quad$ Analysis of variance ANOVA [5; 7]

- $\quad$ Brown - Forsyth test [5; 7]

- $\quad$ Levene test [5; 7]

In manufacturing practice, however, these basic assumptions cannot always be fulfilled (Table 1).

\begin{tabular}{|c|c|c|c|c|}
\hline $\begin{array}{c}\text { Industry/Technology/Quantity } \\
\text { Mechanical Engineering, Automotive Industry } \\
\text { (dimension) }\end{array}$ & - & - & $\begin{array}{c}\text { Constant } \\
\text { Mean } \\
\text { Variance }\end{array}$ \\
\hline $\begin{array}{c}\text { Mechantical Tests (strength, flexibility,...) } \\
\text { Mechanicalence }\end{array}$ & $\mathrm{x}$ & - & - & - \\
\hline Chemistry, Metallurgy (concentration, contents,...) & - & $\mathrm{x}$ & $\mathrm{x}$ & $\mathrm{x}$ \\
\hline
\end{tabular}




\begin{tabular}{|c|c|c|c|c|}
\hline Environment (different concentrations) & $\mathrm{x}$ & $\mathrm{x}$ & $\mathrm{x}$ & $\mathrm{x}$ \\
\hline Electrical Quantities & - & - & - & $\mathrm{X}$ \\
\hline Energy & $\mathrm{X}$ & $\mathrm{x}$ & $\mathrm{x}$ & $\mathrm{X}$ \\
\hline $\begin{array}{c}\text { Plastics, Polymers, Textiles, Physico-mechanical } \\
\text { Quantities }\end{array}$ & $\mathrm{x}$ & - & $\mathrm{x}$ & - \\
\hline Biochemistry, Pharmacy, Food Industry & $\mathrm{x}$ & $\mathrm{x}$ & - & - \\
\hline Economic and Financial Indicators & $\mathrm{x}$ & $\mathrm{x}$ & $\mathrm{x}$ & - \\
\hline Sociology, Human Resources & $\mathrm{x}$ & $\mathrm{x}$ & $\mathrm{x}$ & $\mathrm{x}$ \\
\hline
\end{tabular}

Table 1. Typical breaches of assumptions [8]

The " $x$ " denotes a violation of the assumption, and the "-" designation then determines the predominant fulfillment of the assumption.

\section{Violation of basic data assumptions}

This chapter lists the possible ways of violating the underlying assumptions about the data.

- Violation of the assumption of normality

Unlike the normal probability distribution, the data file may be sloping right or left, or may have different spikes. These violations of normality can be clearly seen on the Q-Q graph. The following 4 images (Figure 1) show the relationship between the histogram (upper image) and the Q-Q graph (bottom image):

a) the concave curve of the Q-Q graph shows a slope to the right and a greater variability of higher values

b) the convex curvature indicates a left slope and a greater variability of lower values

c) the convex concave curve indicates a division with less tails (heavy tails)

d) the concave convex curve shows a division with higher tails (light tails) [20]

e) this image indicates the occurence of an outlier value
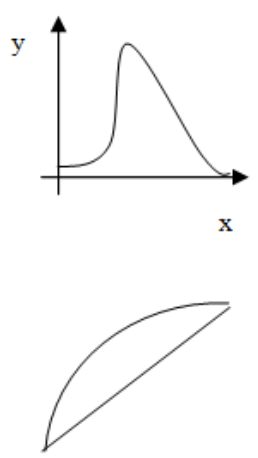

a)
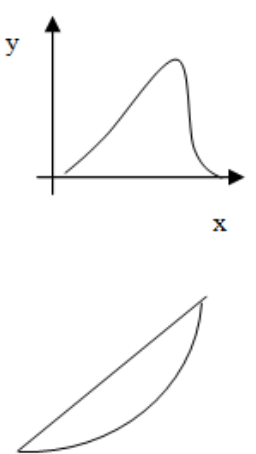

b)
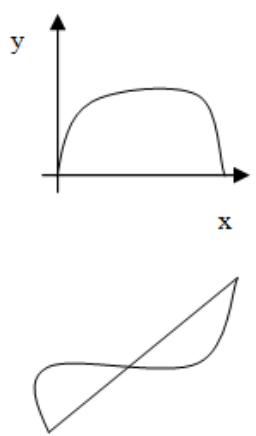

c)

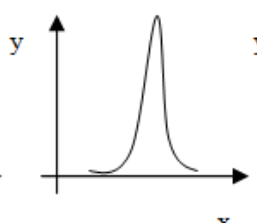

$\mathrm{x}$

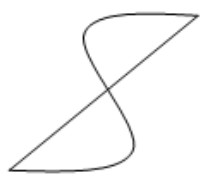

d)

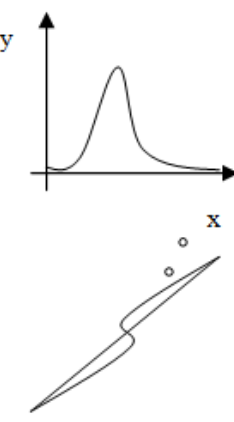

e)

Fig. 1. Relationship of histogram and Q-Q graph

- Violation of the data independence assumption

Independence of data can be verified by the autocorrelation test. Measurement dependency is usually caused by instability of the measuring device, inconstant measurement conditions, neglecting factors that significantly affect measurement results or improper (non-random) sampling. There is a negative and a positive independence. Figure 2 shows the autocorrelation chart: 
a) Negative autocorrelation

b) No dependence

c) Positive autocorrelation [8]

a)

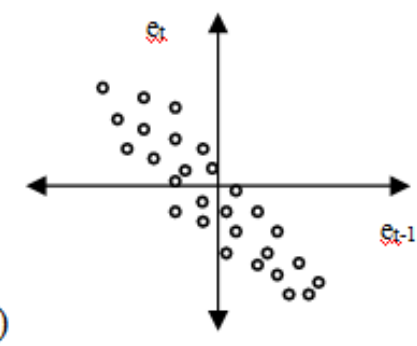

b)

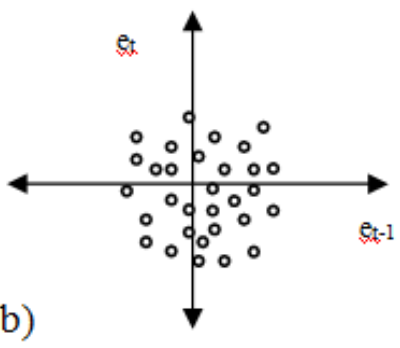

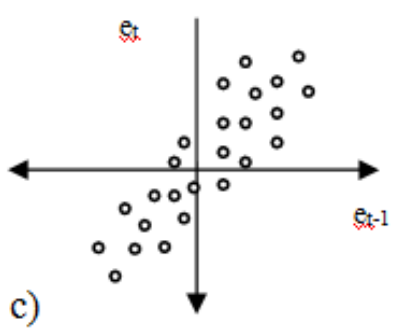

Fig. 2. Chart of autocorrelation

- Violation of the assumption of constant scattering

Constant scatter can be verified using a residual graph. With increasing $\mathrm{x}$, the value of the residue should not increase or decrease, it should still be equidistant from the $\mathrm{x}$-axis. Figure 3 shows:

a) Constant dispersion

b) Non-constant dispersion [8]

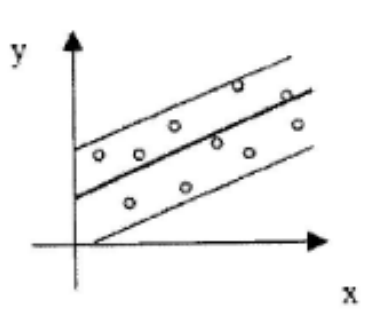

a)

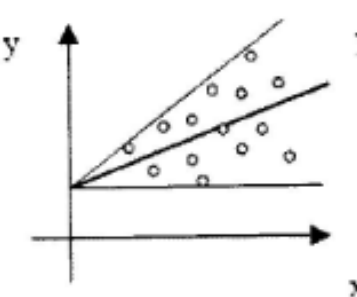

$\mathrm{X}$

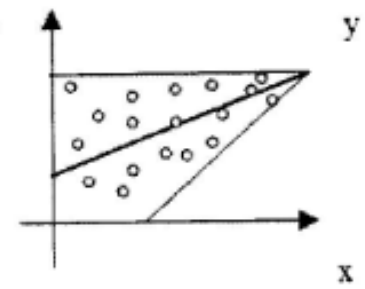

b)

Fig. 3. Non-constant dispersion

- Violation of the assumed constant mean value

Non-compliance with the assumed constant mean value can occur, for example, when changing inputs or technology. The $\mathrm{t}$-test can be used to assess the significance of the difference between the mean values. How the change in the mean value is reflected in the individual value control chart is shown in Figure 4. [8]

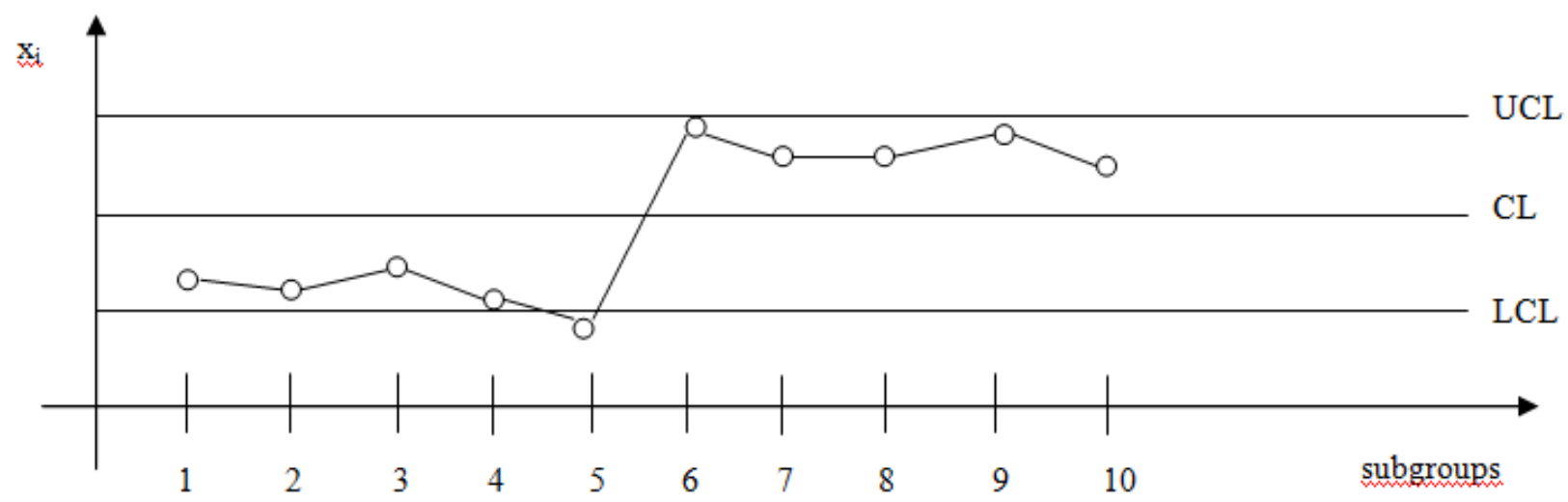

Fig. 4. Change of mean value in individual value control chart 


\section{Nonparametric or robust statistical methods}

Robust statistics attempt to provide appropriate methods that replace commonly used parametric statistical methods but are not affected by remote values or other small deviations from model assumptions. In statistics, classical parametric estimation methods rely on data assumptions (normality, independence, constant mean and scattering) that often are not met in practice. Unfortunately, if data do not meet these assumptions, classical parametric methods often do not provide the right results. For these cases, robust statistical methods have been developed that are not affected by the failure to meet the basic assumptions about the data.

Nonparametric methods are not based on any particular probability distribution and can thus be used when the assumption of normality is not met. Non-parametric methods are more robust than parametric methods. Nonparametric methods can thus be classified as robust.

Roughly speaking, a nonparametric procedure is a statistical procedure that has certain desirable properties. The rapid and continuous development of nonparametric statistical procedures over the past 7 1/2 decades is due to the following advantages enjoyed by nonparametric techniques:

- Nonparametric methods require few assumptions about the underlying populations from which the data are obtained. In particular, nonparametric procedures forgo the traditional assumption that the underlying populations are normal.

- Nonparametric methods enable the user to obtain exact P-values for tests, exact coverage probability for confidence intervals, exact experimentwise error rates for multiplate comparison procedures, and exact coverage probabilities for confidence bands without relying on assumptions that underlying populations are normal.

- Nonparametric methods are often (although not always) easier to apply than their normal theory counterparts.

- Nonparametric methods are often quite easy to understand.

- Although at first glance most nonparametric methods seem to sacrifice too much of the basic information in the sample, theoretical efficiency investigations have shown that this is not the case. Usually, the nonparametric methods are only slightly less efficient that their normal theory competitors, when the underlying populations are normal (the home court of normal theory methods), and they can be mildly or wildly more efficient than these competitors when the underlying populations are not normal.

- Nonparametric methods are relatively insensitive to outlying observations.

- Nonparametric methods are applicable in many situations where normal theory procedures cannot be utilized. Many nonparametric methods require just the ranks of the observations, rather than the actual magnitude of the observations, whereas the parametric methods require the magnitudes. [2]

With regards to the use of these methods at statistical process control, non-parametric and robust control charts have been developed. These control charts are not only suitable for processes that do not meet normality and independence of the data, but especially in the beginning of the SPC implementation, when there are not enough data available. [3]

\section{The future of nonparametric statistical process control}

In recent years, non-parametric and robust control charts have received more attention than it used to be in the past. It is indisputable that they deserve this attention because they form an important part of statistical process control. Already since the 1960s, alternatives to the classical Shewhart control charts have been developed based on a non-normal distribution. In 1958, Ferrell [11] defined a control chart for the lognormal distribution. Nealson [12] obtained in 1979 control limits for median, range scale and location scale for the Weibull distribution. Unlike these control diagrams, the nonparametric ones are more flexible. Since the 1990s, various nonparametric and scrupulous control patterns have been proposed. Alloway and Raghavachary [13] in 1991, and then Pappanastos and Adams [14] in 1996 proposed a control chart for Location based on the Hodgest - Lehmann estimator. Amin, Reynolds and Bakir [15] presented in 1995 a control chart for the process mean and process variability based on the sign statistics.

In 1995, Bai and Choi [16] proposed a regulatory diagram for the sloping distribution. In 2008, Nandini [17] dealt with control charts based on the two sample rank - sum test of Ansari and Bradley. Chakraborti, Mark and Wiel [18] in 2008 engaged in a nonparametric control chart based on the Mann - Whitney statistics. In 2015 Zhang, Chen and Zou [19] suggested a robust multivariate control chart based on the goodness-of-fit test. Unfortunately, this area of statistical process control is not used in practice, it is not a part of courses and publications on statistical process control. There is not even the necessary software support, which could change in the future and these simple methods could become a match for the classical parametric methods. 


\section{Conclusion}

This article summarizes shortcomings of classical Shewhart control charts (such as the need for normal data distribution, mutual data independence, and more). It offers the possibility to use nonparametric methods to eliminate these deficiencies. It presents the advantages of nonparametric methods. The results will contribute to the further development of statistical process control and process capability analysis. The proposed methodology could help in the decision-making processes in practice. In the future, I would like to test different non-parametric control charts on data that violate in different ways basic assumptions for using classical Shewhart control charts. And based on the results, I would elaborate their overview, including a software support.

\section{Acknowledgments}

The work was supported by the specific university research of the Ministry of Education, Youth and Sports of the Czech Republic No.SP 2017/63.

\section{References}

[1] D'Agostino, R. B., et al. (1986). Goodness-of-fit techniques. New York: M. Dekker, ISBN 0824774876

[2] Hollander, M., et al. Nonparametric statistical methods. Third edition. ISBN 978-0-470-38737-5.

[3] Chakraborti, S., et al. (1999). Nonparametric statistical process control : an overview and some results. (Memorandum COSOR; Vol. 9908). Eindhoven: Technische niversiteit Eindhoven.

[4] Ion, R. A. (2001). Nonparametric statistical process control, Ph.D. Dissertation, Korteweg-de Vries Institute for Mathematics, Amsterdam, Netherlands,

[5] Jarosova, E., \& Noskievicova, D. (2015). More advanced methods of statistical process control. 1st ed .. Prague: Grada Publishing. ISBN 978-80-247-5355-3.

Jarošová, E., \& Noskievičová, D. (2015). Pokročilejší metody statistické regulace procesu. 1st ed.. Praha: Grada Publishing. ISBN 978-80-247-5355-3.

[6] Kotlorz, L .. (2012). Normal tests. Prague,. Bc. Dissertation. Charles University in Prague, Prague, Czech republic Kotlorz, L..(2012). Testy normalty. Praha,. Bakalářská práce. Karlova Univerzita v Praze, Praha, Ceská republika

[7] Madansky, A.. (1988). Prescriptions for working statisticians. New York: Springer-Verlag,. ISBN 0387966277.

[8] Meloun, M., et al. (2004). Statistical analysis of experimental data. Ed. 2., eds. Prague: Academia ,. ISBN 80-2001254-0.

Meloun, M., et al.(2004). Statistická analýza experimentálních dat. Vyd. 2., upr. a rožs. Praha: Academia,. ISBN 80-200-1254-0.

[9] Nenadal, J.; Petrikova, R.; Plura, J.; Noskievicova, D. \& Tosenovsky, J. (2008). Modern Quality Management: Principles, Procedures, Methods. Prague: Management Press ,. ISBN 978-80-7261-186-7.

Nenadál, J.; Petříková, R.; Plura, J.; Noskievičová, D. \& Tošenovský, J. (2008). Moderní management jakosti: principy, postupy, metody. Praha: Management Press,. ISBN 978-80-7261-186-7.

[10] Salda, Z. (2010). Measurement uncertainties and statistical models. Bc. Dissertation, Brno University of Technology, Brno, Czech Republic

Šalda, Z. (2010). Nejistoty měření a statistické modely. Bakalářská práce, VUT v Brně, brno, Česká Republika

[11] Ferrell, E. B. (1958). Control charts for Lognormal Universe. Industrial Quality Control 15, pp 4-6.

[12] Nelson, P. R. (1979). Control Charts for Weibull Processes with Standardss Given. IEEE Transactions on reliability 28, pp. 283-287.

[13] Alloway, J. A., et al. (1991). Control chart based onn the Hodges-Lehmann estimator. Journal of Quality Technology 23, pp. 336-347.

[14] Pappanastos, E. A., et al. (1996). Alternative designs off the Hodges-Lehmann control chart. Journal of Quality Technology 28, pp. 213-223.

[15] Amin, R. W., et al. (1995). Nonprametric quality control based on the sign statistic. Communication Statistical Theory and Methods 24, pp. 1597-1623

[16] Bai, D. S., et al. (1995). X and R Control Charts for Skewedd Populations. Journal of Quality Technology 27, pp. 120-131.

[17] Nandini, D., (2008). A Note of the Efficiency of Nonparametric Control Chart for Monitoring Process Variability. Economic Quality Control, vol. 23, No. 1, ISSN 0910-5151.

[18] Chakraborti, S., et al. (2008) A nonparametric control chart based on the Mann-Whitney statistic. Beyond Parametrics in Interdisciplinary Research: Festschrift in Honor of Professor Pranab K. Sen [online]. Beachwood, Ohio, USA: Institute of Mathematical Statistics, pp. 156 [cit. 2017-09-01]. DOI: 10.1214/193940307000000112. ISBN 978-0-940600-73-7.

[19] Zhang, Ch., et al. (2015), Robust multivariate control chart based on goodness-of-fit test.

[20] Sebera, M. Multidimensional Statistical Methods [online]. [feeling. 2017-08-28]. Available from: http://www.fsps.muni.cz/ sebera/vicerozmerna_statistika/pojmy.html

Sebera, M. Vícerozměrné statistické metody [online]. [cit. 2017-08-28]. Dostupné z: http://www.fsps.muni.cz/ sebera/vicerozmerna_statistika/pojmy.html

[21] Kolosowski, M[ariusz]; Duda, J[erzy] \& Tomasiak, J[acek] (2016). Statistical process control in conditions of piece and small lot production, Proceedings of the 26th DAAAM International Symposium, pp.0147-0155, B. Katalinic (Ed.), Published by DAAAM International, ISBN 978-3-902734-07-5, ISSN 1726-9679, Vienna, Austria DOI:10.2507/26th.daaam.proceedings.021 